\title{
Controlled encircling procedure for retinal detachment
}

\author{
A. M. HAMILTON AND W. TAYLOR \\ London
}

The encircling operation for the treatment of retinal detachment is a well established surgical method (Schepens, Okamura, Brockhurst, and Regan, 196o; Regan, Schepens, Okamura, Brockhusrt, and McMeel, 1962; Girard and McPherson, 1962; Schepens, 1964; Brockhurst, 1965; Schepens, 1968). However, complications do occur and a number of these are related to the tightness of the encircling band. Where this produces an insufficient ridge, the indent may not be enough to close the hole. If the ridge is too great problems of anterior segment ischaemia (Schepens, Okamura, and Brockhurst, 1957; O’Day, Galbraith, Crock, and Cairns, I966), strap pain, scleral necrosis (Okamura, 1965; Kurz and Ezrow, 1965), gross reduction of visual field, and meridional folds (Schepens, I964; McDonald, I965; Ferguson, I965) can occur. In an attempt to reduce these complications a method was devised to produce a smooth even ridge of standard depth. A 2-mm. high indenting ridge was arbitrarily selected. The reduction in diameter of a sphere at the site of a 2-mm. indentation would be the initial diameter (D) less $4 \mathrm{~mm}$. (Fig. I).

$\begin{array}{ll}\text { The initial circumference of the sphere } & =\pi \mathrm{D} \\ \text { The circumference at site of indentation } & =\pi(\mathrm{D}-4) \\ \text { Therefore the difference in circumference } & =\pi \mathrm{D}-\pi(\mathrm{D}-4) \\ & =\pi 4 \\ \pi=3.14^{2} & =12.5 \mathrm{~mm} .\end{array}$

(a)

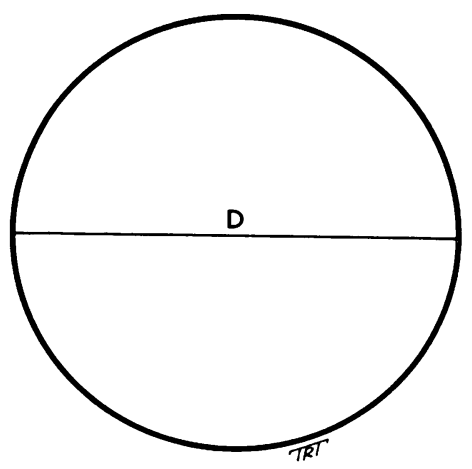

FIG. I Diameter reduction of an indented sphere (b)

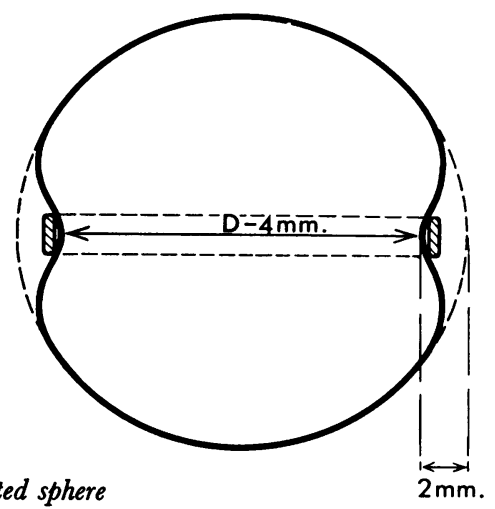


Therefore, if the encircling band is shortened by $12.5 \mathrm{~mm}$., a $2 \mathrm{~mm}$. high indenting ridge should ensue. To test the effectiveness of a controlled shortening of an encircling band fourteen cases of retinal detachment of widely varying types were treated.

\section{Method}

The encircling band is applied to the globe so that the retinal pathology will lie on the anterior slope of the indent. The band is secured in each quadrant by $5 / 0$ braided terylene mattress sutures, so tied that the band is able to slide freely but not to slip forwards or backwards. The band is now drawn up without stretch and the site of the crossing marked with sutures (Fig. 2). This will give the initial circumference $(\pi \mathrm{D})$.

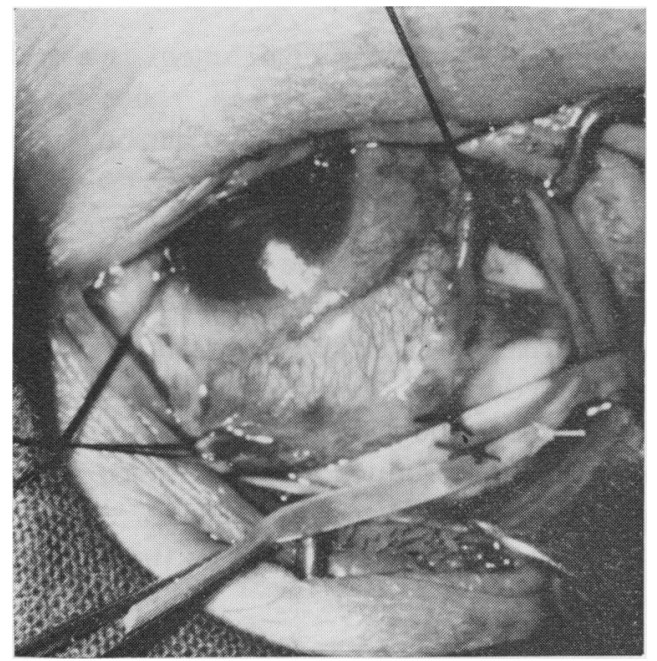

FI G. 2 Marking initial circumference $(\pi \mathrm{D})$ of globe

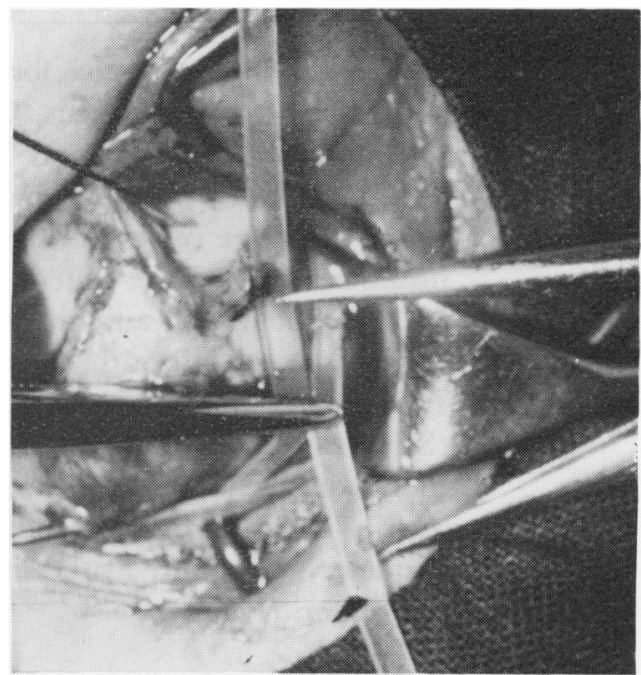

FIG. 3 Measuring shortening of strap

In some cases the shortening of the band can be achieved without release of subretinal fluid. If fluid is released a limited drainage only is done, just sufficient to allow for the shortening of the strap. If excessive fluid is released, the eye must be reconstituted. This is done by injecting, under direct observation, Ringer's solution or air, into the vitreous via the pars plana.

The band is now shortened and the site of crossing is temporarily fixed with artery forceps. The ends are relaxed and the distance between the sutures is measured until the separation of the sutures is $12.5 \mathrm{~mm}$. (Fig. 3). The band is then secured.

In all but one case a $2 \mathrm{~mm}$. silicone rubber strap and cryopexy was used. In this one case a doubled Arruga string was employed and no cryopexy was applied.

\section{Results}

Table I gives clinical details of the fourteen cases. Cases I to io were successfully treated with a single operation. Cases I to 8 had silicone strap, cryopexy, and drainage of subretinal fluid; Case 9 was similarly treated but no subretinal fluid was drained. In Case Io a double Arruga string was used with drainage but no cryopexy. The results of these cases are given in Table II.

Cases I I to I4 required further surgery. In Case I I a hole developed anterior to the ridge 4 months after successful primary surgery and this was treated with plombage, cryopexy, and no drainage. In Case 12 a primary procedure of strap and cryotherapy 
Table I Clinical particulars of fourteen patients

\begin{tabular}{|c|c|c|c|c|c|c|c|c|}
\hline $\begin{array}{l}\text { Case } \\
\text { No. }\end{array}$ & $\begin{array}{l}\text { Age } \\
(y r s)\end{array}$ & $\begin{array}{l}\text { Duration } \\
\text { of retinal } \\
\text { detachment }\end{array}$ & $\begin{array}{l}\text { Retinal } \\
\text { pathology }\end{array}$ & $\begin{array}{l}\text { Vitrcous } \\
\text { pathology }\end{array}$ & $\begin{array}{l}\text { Associated } \\
\text { pathology }\end{array}$ & $\begin{array}{l}\text { Extent of } \\
\text { retinal } \\
\text { detachment }\end{array}$ & $\begin{array}{l}\text { Refractive } \\
\text { error }\end{array}$ & $\begin{array}{l}\text { Preoperative } \\
\text { visual acuity }\end{array}$ \\
\hline $\mathbf{I}$ & 87 & 2 wks & No hole found & Nil & Cataract & Total & $+2 \cdot 00$ & Counting fingers \\
\hline 2 & 57 & 2 mths & $\begin{array}{l}\text { Multiple round } \\
\text { holes }\end{array}$ & $\mathrm{Nil}$ & Nil & Lower $\frac{1}{2}$ & -3.50 & Counting fingers \\
\hline 3 & 23 & $3 \mathrm{mths}$ & $\begin{array}{l}\text { Chorio-retinal } \\
\text { scarring }\end{array}$ & $\begin{array}{l}\text { Extensive } \\
\text { vitreous } \\
\text { traction }\end{array}$ & Aphakic & Total & $+12 \cdot 00$ & Hand movements \\
\hline 4 & 34 & 3 days & $\begin{array}{l}\text { Multiple round } \\
\text { holes }\end{array}$ & Nil & $\begin{array}{l}\text { Previous temporal } \\
\text { half scleral } \\
\text { resection }\end{array}$ & $2 / 3$ & $-14 \cdot 00$ & $6 / 18$ \\
\hline 5 & Io & 3 mths & Dialysis & Nil & Nil & Inferior $\frac{1}{2}$ & $-\mathbf{I} \cdot 00$ & $6 / 24$ \\
\hline 6 & 42 & 2 wks & Macular hole & Nil & $\overline{\mathrm{Nil}}$ & Total & $-1 \cdot 50$ & Hand movements \\
\hline 7 & 54 & 2 days & $\begin{array}{l}\text { Mu!tiple round } \\
\text { holes }\end{array}$ & $\mathrm{Nil}$ & Nil & Upper $\frac{1}{2}$ & $+5 \cdot 00$ & $6 / 36$ \\
\hline 8 & 31 & I wk & $\begin{array}{l}\text { Multiple round } \\
\text { holes and lattice }\end{array}$ & Nil & $\mathrm{Nil}$ & $3 / 4$ & -18.00 & Counting fingers \\
\hline 9 & 71 & 4 days & $\begin{array}{l}\text { Two holes and } \\
\text { lattice }\end{array}$ & $\mathrm{Nil}$ & Aphakic & Total & -13.00 & Hand movements \\
\hline I0 & 53 & 2 mths & No hole visible & $\begin{array}{l}\text { Extensive } \\
\text { exudative } \\
\text { haze }\end{array}$ & $\begin{array}{l}\text { Aphakic with } \\
\text { anterior chamber } \\
\text { implant uveitis }\end{array}$ & Total & +15.00 & Perception of light \\
\hline II & 65 & $2 \mathrm{mths}$ & $\begin{array}{l}\text { Multiple round } \\
\text { holes and lattice }\end{array}$ & Nil & $\mathrm{Nil}$ & Sub-total & $-8 \cdot 50$ & Hand movements \\
\hline 12 & 48 & 2 yrs & $\begin{array}{l}\text { Multiple round } \\
\text { holes and lattice }\end{array}$ & Nil & Nil & Temporal I/3 & $-1 \cdot 75$ & Counting fingers \\
\hline 13 & 75 & 3 wks & No holes found & Nil & Nil & Nasal $\frac{1}{2}$ & $-10 \cdot 00$ & $6 / 18$ \\
\hline 14 & 72 & I wk & Multiple boles & $\mathrm{Nil}$ & Aphakic & $2 / 3$ & $+12 \cdot 00$ & Hand movements \\
\hline
\end{tabular}

Table II Results in ten cases successfully treated

\begin{tabular}{|c|c|c|c|}
\hline $\begin{array}{l}\text { Case } \\
\text { No. }\end{array}$ & $\begin{array}{l}\text { State of } \\
\text { retina }\end{array}$ & $\begin{array}{l}\text { Present visual } \\
\text { acuity }\end{array}$ & $\begin{array}{l}\text { Time of } \\
\text { follow-up (mths) }\end{array}$ \\
\hline I & Flat & $6 / 60$ & 8 \\
\hline 2 & Flat & $6 / 60$ & 5 \\
\hline 3 & Flat & $6 / 18$ & 5 \\
\hline 4 & Flat & $6 / 18$ & 4 \\
\hline 5 & Flat & $6 / 24$ & 3 \\
\hline 6 & Flat & Counting fingers & 3 \\
\hline 7 & Flat & $6 / 9$ & 4 \\
\hline 8 & Flat & Counting fingers & 3 \\
\hline 9 & Flat & $6 / 12$ & 7 \\
\hline 10 & Flat & $6 / 18$ & $\overline{6}$ \\
\hline
\end{tabular}

with no drainage was unsuccessful; I month later a silicone gutter was placed under the strap in one quadrant and subretinal fluid drained with application of further cryopexy. Case 13, in which no hole was found, was unsuccessfully treated with cryopexy, strap, and drainage; further surgery was refused. Case 14, an aphakic, was unsuccessfully 
treated with the initial encirclement and a gutter was placed under the strap at the site of a leaking hole. After this the retina flattened, but 3 months later massive vitreous retraction developed. The results of Cases I I-I4 are summarized in Table III.

Table III Results in four cases requiring additional surgery

\begin{tabular}{|c|c|c|c|}
\hline $\begin{array}{l}\text { Case } \\
\text { No. }\end{array}$ & State of retina & Present visual acuity & $\begin{array}{l}\text { Duration of } \\
\text { follow-up (mths) }\end{array}$ \\
\hline II & $\overline{\text { Flat }}$ & $6 / 36$ & 6 \\
\hline 12 & Flat & Counting fingers & 3 \\
\hline 13 & $\begin{array}{l}\text { Total } \\
\text { detachment }\end{array}$ & $\begin{array}{l}\text { Hand } \\
\text { movements }\end{array}$ & \\
\hline 14 & $\begin{array}{l}\text { Total } \\
\text { detachment } \\
\text { with massive } \\
\text { vitreous } \\
\text { retraction }\end{array}$ & $\begin{array}{l}\text { Perception } \\
\text { of } \\
\text { light }\end{array}$ & \\
\hline
\end{tabular}
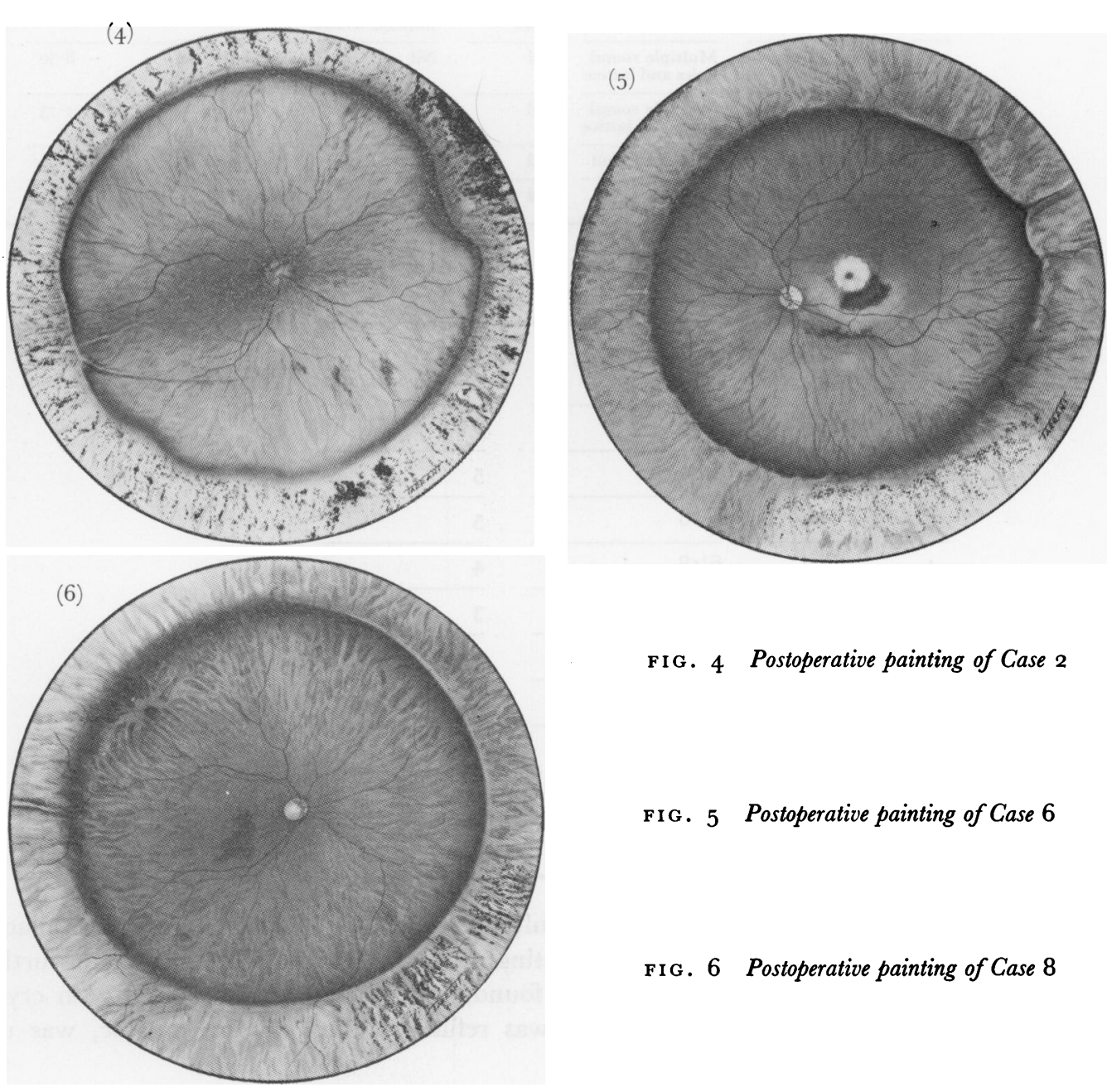

FIG. 4 Postoperative painting of Case 2

FIG. 5 Postoperative painting of Case 6

FIG. 6 Postoperative painting of Case 8 
Using the method we have produced a gentle ridge in all the cases as shown by the postoperative paintings in a selection (Figs 4, 5, 6). Flat retinae have been achieved in all but two. No other complication occurred and in particular we observed no sign of anterior segment ischaemia, no patient complained of strap pain, and meridional retinal folds were not produced.

\section{Discussion}

The difficulty frequently arises as to how much a strap should be shortened (Girard, 1965); this led us to the adoption of the present technique. The temptation to overtighten the strap is always present. This is especially so in a soft eye when the appearance of the indent at the time of surgery is misleading.

Our present indications for the procedure are multiple pathology, aphakic detachment, retinal dialysis, macular hole, vitreous traction, and cases in which no hole is found. In patients with extensive vitreous traction, a more severe indentation may be required. However, in the one case of traumatic vitreous traction, a controlled encirclement was successful.

Whether we should extend this procedure to all cases of retinal detachment is debatable It is usually necessary to drain subretinal fluid even with a controlled encirclement. This can often be avoided with local plombage. However, local plombage does have some disadvantages; a single area of retina treated and the indent is often of a temporary nature. A $360^{\circ}$ indent remains permanently and may protect against subsequent detachment (Urrets-Zavalía, I968).

\section{Conclusion}

The method described gives a smooth even ridge sufficient to serve the purpose for which it was designed without excessive distortion of the globe. We therefore hope that the encircling operation has been converted from an art to a science.

We thank the Consultant Surgeons at Moorfields Eye Hospital for allowing us to operate on their patients, and in particular Mr. Redmond Smith who first introduced the idea to us. We also thank Mr. T. Tarrant for the art work.

\section{References}

BROCKHURST, R. J. (1965) In "Controversial Aspects of the Management of Retinal Detachment", ed.

C. L. Schepens and C. D. J. Regan, p. i i . Churchill, London

FERGUSON, E. C. (1965) Idem, p. I 37

GIRARD, L. J. (1965) Idem, p. I4I

and McPHERson, A. R. (1962) Arch. Ophthal. (Chicago), 67, 409

KURZ, G. H., and EZROW, L. (1965) Ibid., 73, 183

McDoNALD, P. R. (1965) In "Controversial Aspects of the Management of Retinal Detachment",

ed. C. L. Schepens and C. D. J. Regan, p. I35. Churchill, London

O'DAY, D. M., GALBRAITH, J. E. K., GROcK, G. W., and GAIRNS, J. D. (I966) Lancet, 2, 40 I

OKAMURA, I. D. (1965) In "Controversial Aspects of the Management of Retinal Detachment",

ed. C. L. Schepens, and C. D. J. Regan, p. 225. Churchill, London

REGAN, C. D. J., SCHEPENS, C. L., OKAMURA, I. D., BROCKHURST, R. J., and McMEel, J. W. (1962) Arch.

Ophthal. (Chicago), 68, 313

Schepens, c. L. (1964) Trans. Amer. Acad. Ophthal. Otolaryng., 68, 959

(1968) In "New and Controversial Aspects of Retinal Detachment", ed. A. McPherson,

p. 36o. Harper and Row, New York

- OKAMURA, I. D., and BRockhurst, R. J. (1957) Arch. Ophthal. (Chicago), 58, 797

$\longrightarrow$ - - $\longrightarrow$, and REGAN, C. D. J. (I96o) Ibid., 64, 868

uRrets-zavalía, A. (1968) In "New and Controversial Aspects of Retinal Detachment", ed. A.

McPherson, p. 279. Harper and Row, New York 